\title{
THE ILLNESSES AND DEATH OF ROBERT WALPOLE
}

\author{
by
}

\section{EDMUND ANTHONY SPRIGGS*}

ROBERT Walpole, later Earl of Orford, was born in $1676 \dagger$ in East Anglia, where urinary stone was common, and died in 1745 with this condition. The controversy about his death has been described by Jarvis, ${ }^{1}$ who was particularly concerned with the pamphlet war, involving physicians, surgeons, and literary men, which followed it. Viseltear ${ }^{2}$ has more recently written an account of Walpole's last illness, with special reference to the treatment of urinary stone through the ages. My paper approaches the subject rather from the angle of a clinician.

Walpole's mother is said to have had a stone in her kidney. ${ }^{3}$ His brother Horatio is described as having stone ${ }^{4}$ and gout. ${ }^{5}$ His putative youngest son, Horace, produced from his finger a gouty "chalkstone that I believe is worthy of a place in $\mathrm{Mr}$ Hunter's collection of human miseries".4

Walpole is said to have been born of a difficult labour, and to have been fed by a wet-nurse. He was one of a large family "prone to rickets and fever", many of whom died in infancy. ${ }^{5}$ He had severe smallpox at Cambridge, and his physician, Master of Caius and a friend of Walpole's father, said to one of the Fellows of King's, "We must take care to save this young man, or we shall be accused of having purposely neglected him, because he is so violent a Whig". 6

As to Walpole's height, the authorities differ, but there is no disagreement that in

* E. A. Spriggs, D.M., F.R.C.P., Physician, The General Hospital, Newcastle upon Tyne.

$\dagger$ Dates throughout are given as in their sources, except that the year has been changed, when necessary, to accord with our present calendar.

'R. C. Jarvis, 'The death of Walpole: Henry Fielding and a forgotten cause célebre', Modern Language Rev., 1946, 41: 113-130.

2 Arthur J. Viseltear, 'The last illness of Sir Robert Walpole, first Earl of Orford', Bull. Hist. Med., 1967, 41: 195-207.

${ }^{3}$ A letter from a physician in town to another at Bath concerning the case of the Right Honourable the late Earl of Orford, London, M. Cooper, 1745.

‘W. S. Lewis (editor), The Yale edition of Horace Walpole's correspondence, 39+ vols., London, Oxford University Press, 1937-. Horatio Walpole's (his uncle's) stone, 4: 114. Correspondence with Mme Deffand, 4: 135. His own gout, 9: 291. Correspondence with Richard West, 13: 176; Correspondence with Sir Horace Mann, 17: 164, 169, 170, 211, 294; 18: 140, 159, 200, 449, 538, 552, 556; 30: 49. Orford's last words, $26: 12$. Correspondence with Lord Lincoln, 30: 29. Correspondence with Sir C. H. Williams, 30: 49. Correspondence with Orford, 36: 7.

'Sir John H. Plumb, Sir Robert Walpole, 2 vols., London, Cresset Press, 1956 and 1960.

-W. Coxe, Memoirs of the life and administration of Sir Robert Walpole, Earl of Orford, 4 vols., London, Longman, etc., 1816. 


\section{E. A. Spriggs}

maturity he was a huge man. Lady Mary Wortley Montagu? described him in 1734 as "The Potent Knight whose Belly goes At least a Yard before his Nose". This is not very polite, even if one charitably assumes that Lady Mary did not use the word nose in a Shandeian sense. Perhaps Queen Caroline's comment, discussing Walpole's attachment to Miss Skerrit, in 1734, is even more acid: “... avec ce gros corps, ces jambes enflées, et ce vilain ventre...".

\section{EARLY FEVERISH AND OTHER ILLNESSES}

As the first mention of urinary gravel occurs in 1718 , one is left to speculate whether earlier feverish illnesses were related to urinary infection. Plumb $b^{5}$ describes how, in 1705, Walpole went down with fever. It is stated that the illness was partly nervous exhaustion, a release from tension after a period of fierce concentration at the general election. Plumb adds, "Strangely enough, Walpole's career is studded with such feverish illnesses, which always tended to occur after a period of anxious waiting had been eased by success". Then in 1710, again according to Plumb, there was an illness of such severity that Walpole's friends were deeply troubled, and it was with the utmost difficulty that he struggled back from Houghton in January to take part in Dr. Sacheverell's trial. The patient himself wrote 9 that he should be obliged to travel slowly, and this suggests he may already have been suffering from bladder stone. Walpole was ill in 1715, while chairman of the committee to impeach Bolingbroke. There are further references to illness in $1716 .{ }^{10.6} \mathrm{~A}$ 'News Letter' in the Harley papers, dated 19 February $1718,{ }^{10}$ contains the following passage: "Walpole upon a fit of gout and gravel was feverish and blistered, but recovered: he is now again relapsed and blistered. Some say he has somewhat of a palsy, at least a great benumbness of some parts." This statement is important, partly because it is one of the two references I have come across to Walpole having gout. On the other hand, when Horace Walpole wrote to George Montagu in $1760^{4}$ about his own gout, he made the comment, "If either my father or mother had had it, I should not dislike it so much". In those days, gout was, to use a modern expression, overdiagnosed, and the question must remain open. The passage is also most important because of the mention of urinary gravel.

There were further illnesses in 1723 to $1726,{ }^{11,12,13.5}$ but this enormous and sick man continued hunting. From March to May 1727, Walpole, now past the age of fifty, is said to have had gout in both legs, and fever. "He suffered constantly from gravel ...

\footnotetext{
' Robert Halsband (editor), Lady Mary Wortley Montagu. Complete letters, 3 vols., Oxford, Clarendon Press, 1965, vol. 2, p. 98.

Romney Sedgwick (editor), Lord Hervey. Memoirs, London, William Kimber, 1952, p. 128.

- Blenheim Papers, British Library. The classification is being altered, but this is the third letter in 1710.

${ }^{10}$ Royal Commission on Historical Manuscripts, Reports, 81 vols., London, Eyre \& Spottiswoode, 1874-1940. Harley papers, 29: iii, 522, 556. Carlisle papers, 42: 85, 93. Stuart papers, 56: ii, 83, 91. Egmont (Percival) papers, 63: i, 206; ii, 508; iii, 7, 49, 50, 140, 228, 255. Hastings papers, 78: iii, 32.

${ }^{11} \mathrm{~W}$. Munk, The roll of the Royal College of Physicians of London, London, Royal College of Physicians, 1878, vol. 2, p. 52.

12 W. Munk (editor), The gold-headed cane, London, Longmans, Green, 1884, pp. 49-50.

${ }^{13}$ Newcastle Papers, British Library Add. MSS. 32,686, fol. 333.
} 
could not undertake business for many weeks."

The Egmont Papers ${ }^{14}$ describe in 1731, “... it is amazing how he [Walpole] that has frequent attacks of the Gravel and Stone can undergo the Burthen" of civil, military, ecclesiastical, and very troublesome foreign affairs. In 1732, he may have had influenza..$^{10,5}$ More fever occurred in $1738,{ }^{10,4}$ and he was unwell in $1739 .{ }^{10}$

By 1741 , Walpole was an old man in very variable health, ${ }^{4.10}$ and he looked pale when, after his fall from power in 1742, he was introduced into the House of Lords, but that may have been because he did not receive a cordial reception. ${ }^{10}$ Further illness occurred in $1743.4^{4}$ Next year, 1744 , the last one Walpole completed, he became sick in the spring. He was ". . . attacked by an Intermitting Fever; on which occasion he took the Bark, by the Advice of Sir Edward Hulse, with very good Effect, and retired for a short time to Richmond Park. Awaking one day from his accustomed Hour's Sleep after Dinner, he was seized with great Pain in the Head, and Giddiness, violent Sickness at the Stomach, a frequent Inclination to Vomit, intense Pain in his Back, and made Coffee-colour'd Water." 15 He continued to take the bark in different forms for six months, and was bled three times. He became easy when his water ceased to be coffee-coloured after ten days. Ranby, the king's surgeon, thought that concreted matter had moved to the bladder.

There are other accounts 15,4 of deteriorating health, psychological change, and frequent passage of urine, with blood in it (particularly after riding in a coach), and gravel. Walpole travelled to Houghton, his Norfolk country residence, on 17 June 1744.

\section{SOURCES FOR LAST ILLNESS}

The main sources are a series of pamphlets written by the physicians and surgeons who had been involved, and by others. In some cases, the motive was plainly- selfjustification, but the pamphlets were best-sellers, often running into more than one edition, and no doubt the authors, as well as the publishers who stimulated them, received their share of the profits. A collection of these pamphlets, but without two of them, ${ }^{16.17}$ is bound together in the British Library. ${ }^{18} \mathrm{~A}$ similar volume was sold at Sotheby's in $1926 .{ }^{19}$

The first was the Narrative 15 of John Ranby, Orford's surgeon and surgeon to the king. This drew the fire of four anonymous critics, ${ }^{20.21,22.3}$ the third of whom is

\footnotetext{
14 Egmont Papers, British Library Add. MSS. 47,117, fol. 333.

$15 \mathrm{~J}$. Ranby, A narrative of the last illness of the Right Honourable the Earl of Orford from May 1744 to the day of his decease, March the eighteenth following, London, John \& Paul Knapton, 1745.

${ }^{16}$ An epistle from a physician at Bath to Dr. Rock, practitioner in town: occasion'd by the letter from a physician in town to another at Bath; concerning the c-se of the l-te E-of O-d, London, Charles Corbett, 1745.

${ }^{17}$ A letter from Dr. Rock in answer to the epistle from a physician at Bath, London, M. Cooper, 1745.

${ }^{18}$ Tracts relating to the last illness of the Earl of Orford, British Library ref. No. 551, a. 24. (11).

19 Times Literary Supplement, 4 March 1926.

${ }^{20}$ [Anon.], An epistle to John Ranby Esq.. . . on the subject of his narrative of the last illness of the late Earl of Orford, as far as it relates to Sir Edward Hulse, Dr. Jurin and Dr. Crowe, London, Jacob Robinson, 1745 .
} 


\section{E. A. Spriggs}

generally believed to have been one of Walpole's physicians, James Jurin.* Jurin attributes the authorship of the first to Dr. Schaw, physician to the Prince of Wales. He criticizes bitterly all the previous authors, and writes of one of them "... if you must have a Greek Quotation in your Advice: you might have been mannerly enough to give us a Translation: and I am persuaded Mr Ranby would have thought himself much more obliged to you for translating this, than for your Version of his Paragraph in your fourth Page." This is the scholar-physician talking down with a vengeance to the surgeon, Mr. Ranby, who, poor fellow, had no Greek.

Then there are an appendix ${ }^{23}$ to Ranby's Narrative, a supporting pamphlet from a physician at Bath, ${ }^{16}$ an answer to that, ${ }^{17}$ and his reply. ${ }^{24}$ And the crescendo continues with $A$ gothic oration in praise of a bad, a tedious and a puzzling practice in physick..$^{25}$ The most remarkable paper in the series is the last. ${ }^{26}$ The title is The charge to the jury: or, the sum of the evidence, on the trial of A.B.C.D. and E.F. all M.D. for the death of one Robert at Orfud, at a special Commission of Oyer and Terminer held at Justice-College, in $W$-ck-lane [where the college of Physicians was situated], before Sir Asculapius Dosem, Dr Timberhead, and others, their Fellows, Justices, etc. This has been attributed to Henry Fielding, the novelist and magistrate, partly on stylistic grounds (see notes 27 and 1 for Fielding's idiosyncrasies), partly because Fielding's opinions on physicians, surgeons, and lawyers are here faithfully reproduced, ${ }^{28}$ and partly because of similarity with his other occasional pieces. ${ }^{29}$ The matter would seem to be settled by Fielding being named as author in an advertisement appearing in one of his sister's publications. ${ }^{1}$ This attribution is accepted by the British Library catalogue, but curiously The charge to the jury is not mentioned in Homes Dudden's almost exhaustive study of Fielding's writings, ${ }^{27}$ even in the section 'Some works mistakenly attributed to Henry Fielding' - though there is full consideration given to a

\footnotetext{
${ }^{21}$ [Anon.], Advice to John Ranby Esq.. . . with some observations on his narrative of the last illness of the Right Honourable The Earl of Orford, London, W. Bickerton, 1745.

${ }_{22}^{2}$ [J. Jurin, probable author, under pseudonym A Physician], An expostulatory address to John Ranby Esq. occasioned by his treatise on gunshot-wounds and his narrative of the Earl of Orford's last illness, London, M. Cooper, 1745.

* Jurin, who became President of the Royal College of Physicians for a brief period before his death in 1750, is the subject of communications in preparation by $\mathrm{Mr}$. Michael Totton, a direct descendant, and by the present author.

${ }^{23} \mathrm{~J}$. Ranby, An appendix to the narrative of the last illness of the Right Honourable the Earl of Orford, London, John \& Paul Knapton, 1745.

${ }^{24} \mathrm{~A}$ second letter from a physician in town to another at Bath occasioned by Sergeant Ranby's appendix to his narrative of the last illness of the Right Honourable the Earl of Orford, by the author of the former letter, London, M. Cooper, 1745.

${ }^{25}$ [Anon.], A gothic oration in praise of a bad, a tedious and a puzzling practice in physick, London, J. Roberts, 1745.

${ }^{26}$ Sir A. Dosem [pseudonym], The charge to the jury on the trial of A.B.C.D. and E.F. . for the death of one Robert at Orfud, etc., London, M. Cooper, 1745.

${ }^{27}$ F. Homes Dudden, Henry Fielding, his life, works, and times, 2 vols., Oxford, Clarendon Press, 1952, pp. 433-434 about physicians.

${ }^{28}$ Leslie Stephen (editor), H. Fielding. Works, London, Smith, Elder, 1882, vol. 3, pp. 212-214; vol. 10, pp. 168-180, and passim.

${ }^{29}$ I. Williams, The criticism of Henry Fielding, London, Routledge \& Kegan Paul, 1970, pp. 50-54.
} 


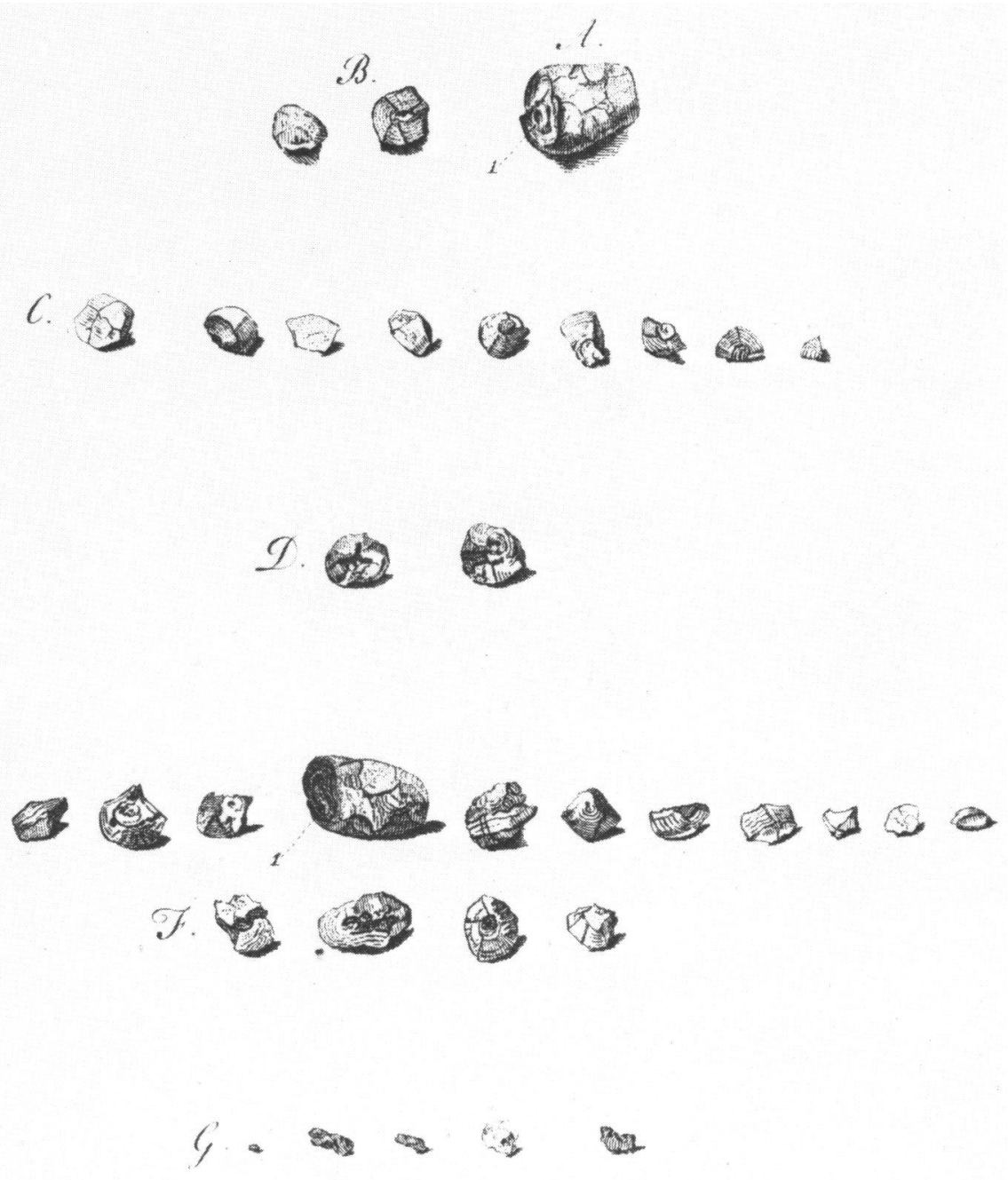

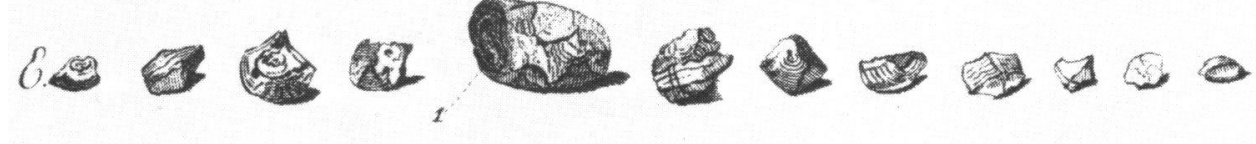
F.

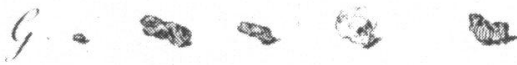

Figure 1. The stones passed by Robert Walpole on 4 February 1745. No scale is given. (From Ranby's Narrative, op. cit., footnote 15, p. 40.) 
different paper of Fielding's with a similar title, Charge to the grand jury.

In The charge to the jury $\mathrm{AB}$ stands indicted "for that he, with a certain deadly Instrument, called a LICKLIVERUM LITHONSKIPTICUM, The Body of the said Robert at Orfud did kill and potion. And the said $\mathrm{CD}$ and EF for being comforting [sic], aiding, abetting, prescribing, dosing, telling and potioning". The point is made that "no Man alive, unless one of the Culprits, knows what this LICKLIVERUM is". The law is parodied: "Now, Gentleman ... you are to know that there are two Sorts of Urine, Urine in Fact, and Urine in Law". The summing-up ends, "Upon the whole, Gentlemen, I think you must acquit the Defendants. Which the Jury immediately did, without withdrawing from the Bar".

The charge to the jury is followed by an advertisement of the library of an eminent physician "who has left off Study", beginning with an apparently reasonable if outdated item and ending with "10. De Ignorantia Celanda: being the Art of Prescribing for a Patient without knowing his Distemper". Appended to this book comes a "Project for the Advancement of Physik in this Island, by abolishing the Coll. etc. Humbled address'd to the said Society.... In order to make your Society some Amends for the Resignation of their Properties it is proposed that the C-ll-ge of Ph-ns be converted into an Hospital, for the Relief and Maintenance of such of your present Members, as through a wrong Education, or a long Perseverance in what is called a Regular Course of Practice, are unqualified to turn Empiricks...". On stylistic grounds, it seems less certain that this paper was written by Fielding.

\section{JURIN'S LITHONTRY PTIC LIXIVIUM}

Now Jurin had a scientific approach to medicine. He wrote about himself " $^{30}$ "for some years past I have been incommoded with gravel of the common red sort ...". At Christmas 1740, he was seized with a severe "nephritic fit", and after a few days voided a rugged red stone the size of a small pea. As symptoms continued, he decided, after considering some of Stephen Hales's experiments, ${ }^{31}$ to try the "Lixivium or Lye" (lix is Latin for lye, from which soap is made by boiling it in fat). First, he succeeded in dissolving with a solution of it the stone he had passed formerly. Then he took it by mouth, gradually increasing the dose over six months up to nine teaspoonfuls a day, and avoiding vinegar, fruit, and wine in order not to counteract the alkalinity. He found himself "by the Blessing of God ... completely cured" and his urine ceased to "furr the Chamber Pot", though he did pass another small stone, the shape and size of an oat, penetrated with small roundish holes, much like those made in books or in wood when worm-eaten, and then two smaller ones.

One of the criticisms which was made against Jurin, in connexion with Orford's death, was that the composition of Jurin's lixivium had never been exactly described. Jurin, in his Expostulatory Address, described above, more or less admits the charge, but makes the case that it would have been unsatisfactory for anyone else to try to prepare the material. Anyway, the anonymous Letter from a physician states, "I have

$30 \mathrm{~J}$. Jurin, The case of James Jurin MD - subjoined to - John Rutty, An account of some new experiments and observations on Joanna Stevens, London, R. Manby, 1742, pp. 41-56.

${ }^{31}$ A. E. Clark-Kennedy, 'Stephen Hales, D.D., F.R.S.', Br. med. J., 1977, iv: 1656-1658. 


\section{E. A. Spriggs}

heard Dr. J. declare publickly, that his Lixivium consists but of three Ingredients, Quick . Lime, Potash, and fair Water".

It may be added that a stone containing urate might well be dissolved, as was Jurin's outside the body, by alkali, and it is possible that by taking an alkaline medicine regularly, a patient might dissolve a bladder stone..$^{32}$

\section{THE LAST ILLNESS}

In November 1744, Orford reluctantly, and with great pain, travelled from Houghton to Arlington Street, London. The king had asked him to come. He decided he would not "be cut", and from 15 December to 4 February he took thirty-six ounces of Jurin's lixivium, probably about half of what Jurin had taken when he was ill with the stone. Orford also took large doses of opium.

The patient's own feelings about his treatment may be gathered from the following passage:

One Evening, as [Dr. Jurin] was sitting by the Bedside, expecting Sir Edward Hulse, Lord Orford was pleased to lay his Hand upon that of Dr. J. as his usual manner was, and to express himself, as near as can be remembered in these Words: Doctor, says he, till now I could never believe, that your Medicine would dissolve, or break, a Stone in the Bladder: You have gained that Point upon me. I find it is a thing of great Efficacy, and I heartily wish good Success to it, both for your Sake, and for the Good of Mankind. But don't you think, added he, pressing the Doctor's Hand gently with his own, it has almost blown me up? Should not that make you very cautious in the Use of it for the Future?24

On 4 February, Ranby extracted from the penis "a Stone exceeding the Dimensions of the largest Kidney-Bean". Later Orford passed blood, partly clotted, "In which were found eleven Pieces of Stones, some of them smooth and rounded on one Side and scraggy on the other; some sharp and pointed on all Sides, as having been inner Parts; but not one of those that did not evidently appear to have been a Part of some larger Stone. These Fragments were whitish; but in the Stones which were entire, the Parts in the Joinings were streaked with Yellow Veins, resembling in some measure Mosaic Pavement. Ten, or twelve of these had very probably been clustered together (with a Nucleus apparently within) something like a large Grape-Stone." A little after 3 p.m., much blood was passed and two larger pieces of stone, and then a lot of clot, and when that had been dissolved in a basin of water, fifteen pieces were found, almost as big as the great one in the morning - it was found to be compacted of three. These were the stones illustrated in Ranby's Narrative (see Fig. 1). The pulse was sinking and "Tendons leaping".

From the time of passing the stones on 4 February, Orford remained incontinent of urine. He was drowsy at times. Although he was thirsty, with a brown, dry tongue, he was "bled eight ounces". On 11 February, Ranby "with his Hands pressed the Bottom of [Orford's] Belly; and the Water gushed out, of a perfect deep Coffee-colour". Then the memory failed, and there were "frequent Twitchings". On 17 February, according to Ranby, "... at the Solicitations of the Physician, I twice attempted to pass the Catheter... these ineffectual Essays determined me to call Mr Cheselden to my

\footnotetext{
${ }^{32}$ M. Peacock and W. G. Robertson, 'Management of urinary stone disease', in W. M. G. Tunbridge (editor), Advanced medicine, London, Pitman Medical, 1981.
} 
Assistance; who succeeded, as it happened, no better than myself." There was an improvement in the latter part of February, but then diarrhoea became troublesome, and Orford died on 18 March 1745.

We have a little more evidence from Horace Walpole's 'Book of Materials', which gives Orford's last words:

"I. Dear Horace, this lixivium has blown me up. 2 [sic]. It has tore me to pieces. The affair is over with me; that it may be short Dr [sic] Ranby, is all I desire. Give me more opium; knock me down. I expect nothing but to have ease. Dear Horace if one must die, 'tis hard to die in pain"'.

"Why do ye all stand round me? are ye all waiting there, because this is the last night."

Walpole insisted on Ranby's telling him if he should die before morning. Ranby gave him no hopes. He then talked in private with Ranby. Then for a quarter of an hour, just before three, he talked with Lord Walpole, and afterwards again with Ranby. He said to Ranby, "'Tis impossible not to be a little disturbed going out of the world, but you see I am not afraid." The same note says that when Sir Robert Walpole was dying, he told Ranby, his surgeon, that he desired his body might be opened. Ranby, acting with great horror cried, "Good God, my Lord, don't talk of that!" "Nay", said Sir Robert, "it will not be till I am dead, and then I shall not feel it - nor you neither."

At post-mortem, the large bladder had thick ridges in its wall, and some small stones. "The Prostate Glands were enlarged, and became harder than they commonly are." Ranby evidently believed that Jurin's lixivium had been harmful, and Horace Walpole thought it lethal. ${ }^{33} \mathrm{Jurin}$ almost admitted this in an appendix to the second edition of his paper on the soap-lye..$^{34}$ But, apart from expressing his outrage at criticism by a mere surgeon, he presses home against Ranby an unanswerable point, "... I should here profess my Amazement that the Urethra escaped Examination [post-mortem]. - the Urethra! in which an Obstruction had more than once foiled your Endeavours to pass the Catheter; and which, being inspected, might have more clearly determined the Seat of the Disease". ${ }^{22}$ This omission was certainly amazing, and I can think of only one possible explanation. Unsuccessful attempts to pass catheters by three determined surgeons were not likely to have left the urethra undamaged. Presumably this was seen or suspected at the post-mortem examination, and the three signatories decided to give no ammunition to potential critics by describing it.

\section{THE DIAGNOSIS IN THE LIGHT OF MODERN KNOWLEDGE}

Physicians or surgeons perusing the above account may be left to reach their own conclusions. For the benefit of others, it may be stated with reasonable confidence that Walpole died of kidney failure after impaction of a large stone in the bladder outlet. The stone broke up, perhaps because of Jurin's treatment with alkali, though that

${ }^{33} \mathrm{H}$. Walpole, Memoirs of the reign of King George the Second, 3 vols., London, Henry Colburn, 1846, vol. 1, p. 225.

${ }_{34} \mathrm{~J}$. Jurin, An account of the effects of soap-lye taken internally, for the stone, in the case of James Jurin, M.D., written by himself, 2nd ed., London, R. Manby \& H. S. Cox, 1745. 


\section{E. A. Spriggs}

treatment may have had severe side-effects. By that time, damage to the urinary system was irreversible. The possibility cannot be excluded that there was some disease of the nervous system also impairing micturition.

\section{ACKNOWLEDGEMENTS}

Professor D. N. S. Kerr has given me good advice about Walpole's illness but is not responsible for what I have written. Mrs. Antoinette Scott has been my patient secretary. 